\title{
The effects of financial inclusion on agricultural productivity in Nigeria
}

\author{
Babajide Fowowe \\ University of Ibadan, Ibadan, Nigeria
}

\begin{abstract}
Purpose - Farmers are the largest group of financially excluded persons in Nigeria, thereby highlighting the supply shortfall in finance to agriculture in Nigeria. Availability of finance would go a long way in improving output and productivity in agriculture, and consequently help in reducing poverty. This study conducts an empirical investigation of the effects of financial inclusion on agricultural productivity in Nigeria.

Design/methodology/approach - This study makes use of the Living Standards Measurement StudyIntegrated Surveys on Agriculture (LSMS-ISA). This is a new data set on agricultural households which contains information on agricultural activities and various household activities, including banking, savings and insurance behaviour. Considering the data are such that there are observations for households over three time periods, the study exploits the time series and cross-section dimension of the data by using panel data estimation.

Findings - The empirical results of the study show that financial inclusion, irrespective of how it is measured, has exerted positive and statistically significant effects on agricultural productivity in Nigeria.

Originality/value - While considerable research has been conducted to examine how finance affects broad macroeconomic aggregates, little is known about the effects of finance at the household and individual level. It is important to explicitly account for financial inclusion when examining the effects of finance on individuals and households. This study improves on existing research and offers new insights into the effects of financial inclusion on the economic activities of agricultural households in Nigeria.
\end{abstract}

Keywords Financial inclusion, Agricultural productivity, Nigeria, Africa, Households in agriculture, Poverty Paper type Research paper

\section{Introduction}

The Nigerian economy was a predominantly agrarian one at independence in 1960, with agriculture contributing $63.8 \%$ to GDP, but the share of agriculture in output has dropped over the years. Agriculture contributed $41.2 \%$ to GDP in 1970, but this had dropped to $20.6 \%$ in 1980. Although it rose to $37 \%$ in 1990 , it had fallen to $27 \%$ in 2000 . New figures based on the rebased GDP show that agriculture's contribution to GDP had fallen further to $23.8 \%$ in $2010,20.2 \%$ in 2014 and $21.42 \%$ in 2018 (Central Bank of Nigeria, 2019). The primary trigger of the decline in agricultural output was the discovery of oil. The country has moved from being self-sufficient in food production to become an importer of food. In 1981, the value of Nigeria's imported food and live animals was N1.8 billion, but this had surged phenomenally to N1.4 trillion by 2018 (Central Bank of Nigeria, 2019).

The 2006 population census put Nigeria's population at 140,003,542, which makes it the country with the largest population in Africa. Nigeria occupies a land area of 923,768 kilometres, thus providing ample land for agricultural production. However, less than $50 \%$ of

\section{JEL Classification - Q12, Q14, G0, O55}

(C) Babajide Fowowe. Published in Journal of Economics and Development. Published by Emerald Publishing Limited. This article is published under the Creative Commons Attribution (CC BY 4.0) license. Anyone may reproduce, distribute, translate and create derivative works of this article (for both commercial and non-commercial purposes), subject to full attribution to the original publication and authors. The full terms of this license may be seen at http://creativecommons.org/licences/by/4.0/ legalcode 
JED

22,1

\section{2}

the cultivable agricultural land is under cultivation by small-holder farmers who use outdated techniques, thereby resulting in low yield (Manyong et al., 2005). The low yield of agricultural production is compounded by a variety of other problems such as poor access to modern inputs and credit, poor infrastructure, inadequate access to markets, land and environmental degradation and inadequate research and extension services (Manyong et al., 2005). These factors, combined with the diminishing income levels of agricultural households, have subsequently exacerbated poverty.

Low agricultural productivity has been identified as an important contributing factor to rural poverty in Nigeria (McKinsey Global Institute, 2014). Nigerian agriculture is characterised by low yields which reflect the dominance of small-holder farmers who lack knowledge about agricultural best practices and are unable to invest in seeds and fertiliser (McKinsey Global Institute, 2014, p. 17). Yield and fertiliser use in Nigerian agriculture are far below the global benchmarks in places such as China, Indonesia, Brazil, India and Ghana, and this is largely as a result of farmers' lack of access to finance (McKinsey Global Institute, 2014, p. 17).

Although the share of agriculture in Nigeria's GDP has fallen significantly, agriculture still remains an important source of livelihood for many Nigerians. Agriculture is the largest employer of labour, with $30.5 \%$ of employed persons engaged in agriculture (National Bureau of Statistics, 2010). There is an even greater percentage of young people engaged in agriculture, as $44 \%$ of youths are employed in agriculture (National Bureau of Statistics, 2013). Thus, agriculture features prominently in the lives of Nigerians, and there is hardly any family that does not have someone involved in agricultural activities.

However, despite agriculture's prominence in economic activities and employment, the sector still suffers from a chronic inability to obtain finance from financial institutions. In the second quarter of 2019, agriculture received only $4.2 \%$ of commercial bank lending, while manufacturing received $15.3 \%$, oil and gas received $22 \%$ and services broadly received $36.5 \%$ (National Bureau of Statistics, 2019). This suggests that agriculture is largely excluded from formal finance. This is supported by recent statistics which show that farmers are the largest group of financially excluded persons in Nigeria, as $37.6 \%$ of farmers are financially excluded (EFINA, 2017). Thus, agriculture is largely excluded from formal finance in Nigeria.

These facts highlight the supply shortfall in finance to agriculture in Nigeria which has contributed to the underinvestment in this sector recorded over the years. Availability of finance would go a long way in improving output and productivity in agriculture. Estimates suggest that availability of finance for African farmers could lead to an increase of over $300 \%$ of agricultural output, from $\$ 280$ billion to $\$ 880$ billion by 2030 (McKinsey Global Institute, 2010). Nigerian agriculture is dominated by small-holder farmers, who contribute over $75 \%$ to agricultural output. These small-holder farmers are characterised by simple techniques of production and bush fallow system of cultivation, thereby leading to low yields and minimal investment in seeds and fertiliser (McKinsey Global Institute, 2014; Aregheore, 2009). Availability of finance would go a long way in improving yields and output of Nigerian agriculture.

While considerable research has been conducted to examine how finance affects broad macroeconomic aggregates, little is known about the effects of finance at the household and individual level. Prior to this time, research has made use of variables measuring financial development, and there has been limited empirical research using variables measuring financial inclusion. This has largely been due to difficulties in measuring financial inclusion across countries and over time, while data are readily available on financial depth (CGAP, 2012). However, results from studies that make use of financial development measures cannot be generalised to cover financial inclusion. This is because, for example, high credit in a financial system could be skewed in favour of the wealthiest individuals and largest firms in the society, thus leading to a situation where the popular measures of financial development 
are capturing financial inequality, and not financial inclusion (GFDR, 2014). The implication of this is that financial depth and financial inclusion are distinct dimensions of financial development, and financial systems can become deep without delivering access for all (Demirguc-Kunt and Klapper, 2012). This has indeed been borne out by the data where use of formal accounts by the poorest group in the population is not correlated to private credit (Demirguc-Kunt and Klapper, 2012). Thus, it is important to explicitly account for financial inclusion when examining the effects of finance on individuals and households.

This study improves on existing research and offers new insights into the effects of financial inclusion on the economic activities of agricultural households in Nigeria. Since a large proportion of the Nigerian population is engaged in agriculture and are rural dwellers; and since there is a higher incidence of poverty in rural areas, an examination of agricultural households will be particularly insightful in understanding poverty in Nigeria. Also, rather than using broad macroeconomic measures of financial development, we will use new data that explicitly measure access to and use of financial services by households, thus providing a proper measure of financial inclusion. This study makes use of the Living Standards Measurement Study-Integrated Surveys on Agriculture (LSMS-ISA), which provides data on households, to examine how financial inclusion has affected agricultural productivity of households in Nigeria. This will provide important insight concerning whether financial inclusion affects agricultural productivity in Nigeria, and the results will prove useful in designing policies aimed at low agricultural productivity and ultimately poverty in Nigeria.

\section{Financial inclusion and agricultural productivity - the nexus}

The finance-growth nexus has featured prominently in economic research over the past quarter of a century. This considerable attention has been spurred in no small way by King and Levine's (1993) seminal paper on the effects of financial sector development on economic growth. Pasali's (2013) synthesis paper surveyed over 100 papers of the finance-growth nexus and concluded that financial sector depth has a statistically significant and economically meaningful positive effect on economic growth (Pasali, 2013, p. 3). This can be attributed to the fact that the financial system performs a number of functions which enable it to attract deposits and ensure a better and more efficient allocation of resources, thereby leading to growth of the economy. The mechanisms through which the financial sector positively affects economic growth have been highlighted by Levine (2005), who identified five ways in which the financial sector enhances growth. Firstly, the financial sector mobilises and pools savings; second, the financial system helps to pool, hedge and trade risk. Third, the financial sector works in monitoring firms and exerting corporate governance; fourth, the financial system produces information and allocates capital. Fifth, the financial system eases the exchange of goods and services.

There are a number of ways through which finance can directly affect poverty and inequality. First, the development of the financial sector can ease the credit constraints hitherto faced by poor households and which limited their abilities to undertake productive investment. Secondly, the broadening of the financial sector and subsequent entrance of new players enhance competition between financial intermediaries, and this leads to a provision of better services and financial products which will improve the quality of lives of poor households (Beck et al., 2007). Thirdly, because financial intermediaries help to pool and limit risk, the problems of asymmetric information peculiar to financial markets are reduced, and this results in a more stable macroeconomic environment which is beneficial to the poor. A developed financial system would also lead to better loan recovery rates because of an advanced supervisory and monitoring capacity. Finally, bigger and more powerful financial intermediaries have abilities to bear the high costs of small credits (Rajan and Zingales, 2001). 
JED

22,1

64

Chigumira and Masiyandima (2003) note that lending to the poor is more costly than to the rich, and consequently, the marginal cost of lending to the poor is higher than that of lending to the rich (p. 28). The financial intermediaries could bear such costs with the long-run in view, assuming small- and medium-scale enterprises will graduate into large-scale businesses in the future.

Financial inclusion can be said to be the proportion of individuals and firms that use financial services (GFDR, 2014, p. 15). Financial inclusion encompasses the range, quality and availability of financial services to the underserved and the financial excluded (IFC, 2011, p. 2). Financial inclusion has featured high on the agenda of development agencies, with the United Nations declaring 2005 as the Year of Microfinance, the Maya Declaration made by Alliance for Financial Inclusion (AFI) members and the G-20 Financial Inclusion Action Plan made in Pittsburgh in 2009. These commitments were made with the sole purpose of achieving inclusive financial systems. With inclusive financial systems, a high proportion of the population will use financial services, and this affords both households and firms the opportunities for external finance which contributes to reducing income inequality and achieving faster economic growth (GFDR, 2014, p. 15).

The effects of financial inclusion on agriculture draw from the role finance plays in affecting poverty and inequality. Availability of finance leads to increased agricultural productivity and higher incomes for the farmer. As a result of this, hunger of the poor is reduced, and they are able to escape poverty traps and withstand periodic hock (Nathan Associates, 2015). With financial inclusion, rural dwellers are offered a diverse array of financial services which helps them in money management and alternative investment outlets. Financial inclusion can affect agriculture in three distinct ways (Nathan Associates, 2015).

Firstly, finance can boost agricultural productivity. Provision of credit facilitates the purchase of inputs and hiring of labour and machines, and this helps to keep the crop cycle going even after harvesting. The seasonal nature of agriculture means that farmers often have to wait several months to be able to plant during the rainy season. Smallholder farmers would have already consumed all the proceeds from the previous harvest and would have no money to buy inputs, or even if they had, they would not have sufficient funds to purchase machinery, fertilisers or seeds. Financial inclusion can help in mitigating these types of problems, as financial products are available in the form of credit or even savings products.

Secondly, finance facilitates diversification of livelihoods and increase in income of farmers. Access to credit can facilitate investment in storage facilities, which will help in keeping produce fresh during transportation. Thus, farmers can get better prices for their products by transporting them to the markets with best prices rather than having to dispose them quickly because of the perishable nature of the products. Also, better storage facilities mean that farmers do not have to sell during harvest when prices are low, but they can wait until when prices rise, thereby increasing their incomes. Availability of credit also provides funds for farmers to add value to products through processing. Improvements in raw farm produce through processing add value, and thus the farmers can get better prices for their products.

Thirdly, financial inclusion helps in promoting resilience and avoiding poverty traps. It has been found that the poor value savings more than credit. Savings facilitate investment which is devoid of interest payments, and so the farmers can be more innovative without the fear or burden of interest payments. Also, savings serve as a buffer against shocks either during unfavourable climatic conditions or during the off-harvest periods. Financial inclusion in this regard through the provision of insurance against agricultural risk, such as weather, crop yields and livestock mortality, would go a long way in avoiding poverty traps and promoting resilience. 


\section{The data - living standards measurement study - Integrated Surveys on Agriculture (LSMS-ISA) or general household surveys (GHS) in Nigeria}

This study makes use of data on agricultural households from the General Household Survey (GHS)-Panel for 2010-2011, 2012-2013 and 2015-2015. The GHS-Panel surveys are undertaken by Nigeria's National Bureau of Statistics (NBS), in collaboration with the Federal Ministry of Agriculture and Rural Development (FMA\&RD), the National Food Reserve Agency (NFRA), the Bill and Melinda Gates Foundation (BMGF) and the World Bank (WB). The GHS-Panel is part of the World Bank's LSMS-ISA which is being undertaken in eight African countries. The purpose of the LSMS-ISA project is to collect panel data on households, their characteristics, welfare and their agricultural activities over the long term. The LSMS-ISA has the overarching objective of improving our understanding of agriculture in sub-Saharan Africa - specifically, its role in household welfare and poverty reduction. The data will also provide insights into how innovation and efficiency can be fostered in the agriculture sector (National Bureau of Statistics, 2015a, p. 2).

The GHS-Panel survey responds to the needs of the country, given the dependence of a high percentage of households on agricultural activities in the country, for information on household agricultural activities along with other information on the households like human capital, other economic activities and access to services and resources (National Bureau of Statistics, 2015a, p. 1). The ability to follow the same households over time makes the GHSPanel a new and powerful tool for studying and understanding the role of agriculture in household welfare over time, as it allows analyses to be made of how households add to their human and physical capital, how education affects earnings and the role of government policies and programmes on poverty, inter alia (National Bureau of Statistics, 2015a, p. 1).

The GHS-Panel survey applies to 5,000 households of the GHS cross-section (22,000 households), collecting additional data on multiple agricultural activities and on household consumption. The first wave of the survey was carried out in two visits to the panel households (post-planting visit in August-October 2010 and post-harvest visit in FebruaryApril 2011) (National Bureau of Statistics, 2015a, p. 1). The second wave of the GHS-Panel was carried out in two visits (post-planting visit in September-November 2012 and post-harvest visit in February-April 2013) (National Bureau of Statistics, 2015b, p. 5). The third wave of the GHS-Panel was carried out in two visits (post-planting visit in September-November 2015 and post-harvest visit in February-April 2016) (National Bureau of Statistics, 2016, p. 5). Due to a number of limitations such as relocation, it was not possible to obtain data for all households that were surveyed in the first wave. Thus, the number of households in the subsequent waves was less than 5,000. Specifically, a total of 4,716 household were surveyed in the second wave (2012-2013), and 4,581 households were surveyed in the third wave (20152016) (National Bureau of Statistics, 2016).

The data on agriculture provide insight on agricultural activities such as crop farming, livestock farming and other agricultural related activities. Specifically, the agricultural database contains information on the number of plots cultivated by households, agricultural inputs used and amount realised from sales of agricultural products. This study focused on crop farming. Since not all households were engaged in crop farming, the total number of households with information on agricultural productivity measured using income from crop farming is approximately half of the households covered in the three waves. In specific terms, a total of 7,183 observations were used in this study: 2,391 observations in the first wave (2010-2011), 2,339 observations in the second wave (2012-2013) and 2,453 observations in the third wave (2015-2016).

The GHS-Panel survey compiles data on a broad range of agricultural information. The agriculture questionnaire collects information on diverse agriculture-related variables such as land ownership and use, farm labour, inputs use, GPS land area measurement and coordinates of household plots, agricultural capital, irrigation, crop harvest and utilisation,
Agricultural productivity in Nigeria 
JED

22,1

66

animal holdings and costs and household fishing activities (National Bureau of Statistics, 2015a).

The GHS-Panel household questionnaire collects information on a broad range of household information such as demographics, education, health, labour, food and non-food expenditure, household non-farm income-generating activities, safety nets and housing conditions. The data also contain information on the head of the household.

Crucially for our purposes, the GHS-Panel household questionnaire also collects data on banking and savings. Until recently, little was known about access to and use of financial services by individuals. Little had been known about the global reach of the financial sector the extent of financial inclusion and the degree to which such groups as the poor, women and youth are excluded from formal financial systems (Demirguc-Kunt and Klapper, 2012, p. 1). Thus, very little was known about financial inclusion, primarily because of lack of data. These data constraints have been mitigated in recent times with the availability of new data on financial inclusion from the Global Financial Inclusion (Global Findex) Database (Demirguc-Kunt and Klapper, 2012).

\section{Research methodology}

This study examines the effects of financial inclusion on agricultural productivity of households in Nigeria. In order to achieve this, we will estimate the following broad model:

$$
A G R I C=\alpha_{0}+\alpha_{1} F I+\alpha_{2} H+\propto_{3} H H+\alpha_{4} A I+\varepsilon_{1}
$$

where AGRIC $=$ agricultural productivity

$$
\begin{aligned}
& \mathrm{FI}=\text { variables capturing financial inclusion } \\
& \mathrm{H}=\text { variables capturing household characteristics } \\
& \mathrm{HH}=\text { variables capturing household head characteristics } \\
& \mathrm{AI}=\text { variables capturing agricultural inputs }
\end{aligned}
$$

Considering the data are such that we have observations for households over three time periods, we need to exploit the time series and cross-section dimension of the data. Consequently, panel data estimation is applied.

Measurement of the two principal variables of interest, namely, agricultural productivity and financial inclusion, is important for this analysis.

Agricultural productivity is broadly identified as the ratio of agricultural outputs to agricultural inputs. Dewett and Singh (1966) defines agricultural productivity as the varying relationship between agricultural output and one of the major inputs, while holding other complementary factors the same. It is generally agreed that agricultural productivity arises as a result of more efficient use of one or more of the three factors of production: land, labour and capital. These give rise to three broad categorisations of agricultural productivity: land, labour and capital productivity.

Based on the data available, this study makes use of land productivity to measure agricultural productivity. Following other studies (Oseni et al., 2014; Ali et al., 2016; Amare et al., 2018; Darko et al., 2018), we capture agricultural productivity with the agriculture (crop) income per hectare (AGRICPROD). Hectare was computed by summing up the land area of the harvested farmland plots. This is because a farmer could harvest crop(s) from more than one plot. To ensure that the estimated harvested farm land is accurate, we dropped plots with sizes that fell within the top 5\%. Also, by dropping the top 5\% plot sizes, we were able to eliminate errors associated with entering of large farmland size. Thereafter, agricultural productivity was obtained by dividing total crop income by land area harvested. Since 
outliers could affect the accuracy of our findings, we dropped households with agricultural productivity that fell within the top $5 \%$ and the bottom $5 \%$.

There are other measures of agricultural productivity in the literature. However, the use of agricultural income per hectare is a better measure of agricultural productivity, because this measure provides information about whether or not farm land was put in efficient use. For example, if there are two farmers, Farmer A and Farmer B, and Farmer A makes use of two hectares of farmland and realised a total of 1,000 crop income, which resulted into a total of 500 crop income per hectare. Farmer B makes use of 0.5 ha of farm land and realised a total of 500 crop income, which resulted into a total of 1,000 crop income per hectare. Here, it is observed that Farmer B has more crop income per hectare than Farmer A. It can then be inferred that Farmer B makes more efficient use of the farm land than Farmer A. Thus, Farmer B is more productive than Farmer A.

The Global Findex database classifies financial inclusion indicators broadly along three dimensions: (i) ownership and use of an account at a formal financial institution, (ii) saving behaviour and (iii) borrowing (Demirguc-Kunt and Klapper, 2013, pp. 283-284).

In line with the three classifications of the Global Findex database, we follow other studies (Soumare et al., 2016; Fowowe and Folarin, 2019; Anzoategui et al., 2014) in capturing financial inclusion using three measures. The first measure is financial access (ACCESS), which provides information on households who have a bank account. This can be subdivided into the formal and informal components. The formal component corresponds to having an account with either a formal or semi-formal financial institution (commercial banks and other financial institutions such as microfinance institutions, cooperative societies and savings associations). The informal component corresponds to having an account with an informal savings group (adashi/esusu/ajo). Our measure of financial access (ACCESS) makes use of the formal component. The second measure of financial inclusion is borrowing or credit (BORROW). This measure provides information on households who have borrowed money either from formal or semi-formal financial institutions. The third measure of financial inclusion is saving (SAVE) which captures using either a formal or semi-formal financial institution to save.

The household characteristics included are household consumption (HC), household net worth (HNW), household size (HS), household religion (HREL), household location (HL) and remittances received by the household (HREM). In addition, the characteristics of the household head are included in the estimations. These are age of the household head (HHA), education of the household head (HHE), gender of the household head (HHG) and occupation of the household head (HHO).

Finally, some variables are included to capture agricultural inputs. These are the quantity of fertiliser used (FT), quantity of herbicide used (HB) and quantity of pesticide used (FT).

Following from the above, because three dimensions of financial inclusion are considered, we cannot include all dimensions in a single equation. Thus, each dimension of financial inclusion has to be included separately in the equations. Thus, FI which captures financial inclusion in equation 1 will have three dimensions. Consequently, the model to be estimated will change from equation 1 to equations 2 to 4 below. The difference between equations 2 to 4 are the alternative measures of financial inclusion included in each equation. The first dimension of financial inclusion (ACCESS) is included in equation 2. The second dimension of financial inclusion (BORROW) is included in equation 3, while the third dimension of financial inclusion (SAVE) is included in equation 4. Thus, the equations to be estimated will take the form:

$$
\begin{aligned}
\mathrm{AGRICPROD}_{i t}= & \beta_{0}+\beta_{1} \mathrm{ACCESS}_{i t}+\beta_{2} \mathrm{HNW}_{i t}+\beta_{3} \mathrm{HC}_{i t}+\beta_{4} \mathrm{HS}_{i t}+\beta_{5} \mathrm{HREL}_{i t} \\
& +\beta_{6} \mathrm{HL}_{i t}+\beta_{7} \mathrm{HREM}_{i t}+\beta_{8} \mathrm{HHA}_{i t}+\beta_{9} \mathrm{HHE}_{i t}+\beta_{10} \mathrm{HHG}_{i t} \\
& +\beta_{11} \mathrm{HHO}_{i t}+\beta_{12} \mathrm{FT}_{i t}+\beta_{13} \mathrm{HB}_{i t}+\beta_{14} \mathrm{PT}_{i t}+\xi_{i t}
\end{aligned}
$$

Agricultural productivity in Nigeria 
JED

22,1

68

$$
\begin{aligned}
\text { AGRICPROD }_{i t}= & \gamma_{0}+\gamma_{1} \mathrm{BORROW}_{i t}+\gamma_{2} \mathrm{HNW}_{i t}+\gamma_{3} \mathrm{HC}_{i t}+\gamma_{4} \mathrm{HS}_{i t}+\gamma_{5} \mathrm{HREL}_{i t} \\
& +\gamma_{6} \mathrm{HL}_{i t}+\gamma_{7} \mathrm{HREM}_{i t}+\gamma_{8} \mathrm{HHA}_{i t}+\gamma_{9} \mathrm{HHE}_{i t}+\gamma_{10} \mathrm{HHG}_{i t} \\
& +\gamma_{11} \mathrm{HHO}_{i t}+\gamma_{12} \mathrm{FT}_{i t}+\gamma_{13} \mathrm{HB}_{i t}+\gamma_{14} \mathrm{PT}_{i t}+\mu_{i t} \\
\mathrm{AGRICPROD}_{i t}= & \delta_{0}+\delta_{1} \mathrm{SAVE}_{i t}+\delta_{2} \mathrm{HNW}_{i t}+\delta_{3} \mathrm{HC}_{i t}+\delta_{4} \mathrm{HS}_{i t}+\delta_{5} \mathrm{HREL}_{i t} \\
& +\delta_{6} \mathrm{HL}_{i t}+\delta_{7} \mathrm{HREM}_{i t}+\delta_{8} \mathrm{HHA}_{i t}+\delta_{9} \mathrm{HHE}_{i t}+\delta_{10} \mathrm{HHG}_{i t} \\
& +\delta_{11} \mathrm{HHO}_{i t}+\delta_{12} \mathrm{FT}_{i t}+\delta_{13} \mathrm{HB}_{i t}+\delta_{14} \mathrm{PT}_{i t}+v_{i t}
\end{aligned}
$$

\section{Results and discussion}

\subsection{Descriptive statistics}

Descriptive statistics are presented in Table 1 . Table 1 presents summary statistics for all three waves in the GHS-Panel data set. There are a total of 7,183 households. The data are an amalgamation of the agriculture and household data sets. While the total observations of the combined agriculture and household data sets are 14,143, the sample is lower because we are interested in only households involved in agriculture. Our measure of agricultural productivity, the crop income per hectare, has an average of 397,999. This implies that the average income for the household in the sample over the three years is N387,999. There is substantial variation in the income, however, as evidenced by the high standard deviation of $500,819.5$. The lowest income-earning household received an average of N17,857.14 over these three years, while the highest income earning household received N3,139,098.

For the financial inclusion measures, the figures indicate the percentage of households that are financially included. Thus, for the first financial inclusion measure (ACCESS), the mean value of 0.315 implies that, on average, $31.5 \%$ of households in our sample have an account at a financial institution either directly, or have access to an account at a financial institution through a family member or close friend. For the second financial inclusion measure (BORROW), the mean value of 0.090 indicates that, on average, $9 \%$ of the households have borrowed from a financial institution in the six months prior to the survey. For the third financial inclusion measure (SAVE), the average value of 0.245 means that $24.5 \%$ of households have used a financial institution to save in the six months prior to the survey. These figures indicate very low levels of borrowing by households. This cannot be unconnected to the high interest rates in Nigeria. Between 2011 and 2018, the lowest monetary policy rate of the Central Bank of Nigeria $(\mathrm{CBN})$ was $11 \%$. This rate has been constant at $14 \%$ since the third quarter of 2016 . This indicates that the high cost of obtaining loans in Nigeria is deterring borrowing. The figures for savings are better, with about one quarter of households saving at financial institutions. Overall, financial inclusion is low. This is a far cry from the CBN's formal financial inclusion target, set in 2012, of $70 \%$ financial inclusion by 2020. This necessitated a revision of the financial inclusion strategy (Central Bank of Nigeria, 2018).

Harvested food crops, which constitute the largest proportion of crops, are divided into five groups that correspond to five of the 15 groups that comprise the dietary diversity measure. Table 1 shows that cereals and grains are the largest crop groups grown, with 95.5\% of households involved in growing this crop group. Roots and tubers are the second most popular crop groups, with $39.7 \%$ of households growing them. In all, $36.4 \%$ of households grew legumes; $33.1 \%$ of households grew sugar, vegetables and oil; and $26.7 \%$ of households grew fruits and vegetables. Non-food crops constitute a very small fraction, as only about $1 \%$ of households grew non-food crops. 


\begin{tabular}{|c|c|c|c|c|c|c|}
\hline & Min & Max & Mean & $\begin{array}{l}\text { Standard } \\
\text { deviation }\end{array}$ & $\begin{array}{c}\text { No of } \\
\text { observation }\end{array}$ & $\begin{array}{l}\text { Agricultural } \\
\text { productivity in }\end{array}$ \\
\hline Agric. productivity (AGRICPROD) & 17857.14 & 3139098 & 387999 & 500819.5 & 7183 & \\
\hline Financial inclusion (ACCESS) & 0 & 1 & 0.315 & 0.464 & 7183 & \\
\hline Financial inclusion (SAVE) & 0 & 1 & 0.245 & 0.430 & 7183 & \\
\hline Financial inclusion (BORROW) & 0 & 1 & 0.090 & 0.287 & 7183 & \\
\hline Household net worth (HNW) & 800 & 12500000 & 544032.5 & 1277624 & 7021 & 69 \\
\hline Household consumption (HC) & 33981.91 & 1827612 & 306815.7 & 221845.5 & 7108 & \\
\hline Household size (HS) & 1 & 31 & 6.301 & 3.221 & 7179 & \\
\hline Christianity adherent (HREL) & 0 & 1 & 0.521 & 0.518 & 7142 & \\
\hline Islam adherent (HREL) & 0 & 1 & 0.469 & 0.499 & 7142 & \\
\hline Traditional religion adherent (HREL) & 0 & 1 & 0.009 & 0.096 & 7142 & \\
\hline Dummy for urban dweller (HL) & 0 & 1 & 0.120 & 0.325 & 7183 & \\
\hline Remittances received (HREM) & 0 & 1 & 0.023 & 0.148 & 7183 & \\
\hline Household head age (HHA) & 16 & 112 & 51.974 & 14.710 & 7170 & \\
\hline $\begin{array}{l}\text { Household head education: Years of } \\
\text { formal education (HHE) }\end{array}$ & 0 & 23 & 6.368 & 6.014 & 7183 & \\
\hline $\begin{array}{l}\text { Household head education: } \\
\text { Level (HHE) }\end{array}$ & 0 & 3 & 0.997 & 0.980 & 7183 & \\
\hline Household head is female (HHG) & 0 & 1 & 0.126 & 0.332 & 7183 & \\
\hline Household head is worker (HHO) & 0 & 1 & 0.109 & 0.312 & 7183 & \\
\hline Household head is farmer (HHO) & 0 & 1 & 0.889 & 0.315 & 7183 & \\
\hline $\begin{array}{l}\text { Household head is } \\
\text { entrepreneur (HHO) }\end{array}$ & 0 & 1 & 0.305 & 0.461 & 7183 & \\
\hline Dummy for fertiliser (FT) & 0 & 1 & 0.504 & 0.500 & 7183 & \\
\hline Dummy for herbicide (HB) & 0 & 1 & 0.296 & 0.457 & 7183 & \\
\hline Dummy for pesticide (PT) & 0 & 1 & 0.219 & 0.414 & 7183 & \\
\hline \multicolumn{7}{|l|}{ Crop group } \\
\hline Cereal/Grain & 0 & 1 & 0.955 & 0.208 & 7183 & \\
\hline Legume & 0 & 1 & 0.364 & 0.481 & 7183 & \\
\hline Root and tuber & 0 & 1 & 0.397 & 0.489 & 7183 & \\
\hline Sugar, beverages and oil & 0 & 1 & 0.331 & 0.471 & 7183 & Table 1 \\
\hline Fruit and vegetable & 0 & 1 & 0.267 & 0.442 & 7183 & Summary statistics - \\
\hline Non-food & 0 & 1 & 0.008 & 0.092 & 7183 & full panel (3 waves) \\
\hline
\end{tabular}

\subsection{Empirical results}

The results of the empirical estimations of the effects of financial inclusion on agricultural productivity are presented in Tables 2-4. Although the models specified in Equations (2) to (4) posit that financial inclusion affects agricultural productivity, it is also possible that agricultural productivity affects financial inclusion. Thus, it is possible that as agricultural productivity increases, then households have more financial resources, and, consequently, have the need and ability to access financial services. Also, general/community-wide increases in agricultural productivity will boost general economic activities, leading to an expansion of the financial sector, thereby leading to more exposure to financial services by households and businesses. The implication of this is that it could be difficult to extract causality between agricultural productivity and financial inclusion. In light of this, we conducted instrumental variable estimation to address the potential endogeneity bias arising from the possible reverse causality between agricultural productivity and financial inclusion. We follow previous research in examining the effect of the exogenous impact of financial inclusion on variables of interest (Beck et al., 2007; Clarke et al., 2006).

Following from this, we make use of instrumental variables estimation, using two instrumental variables. Our first instrumental variable is the presence of a bank within the 
JED

70

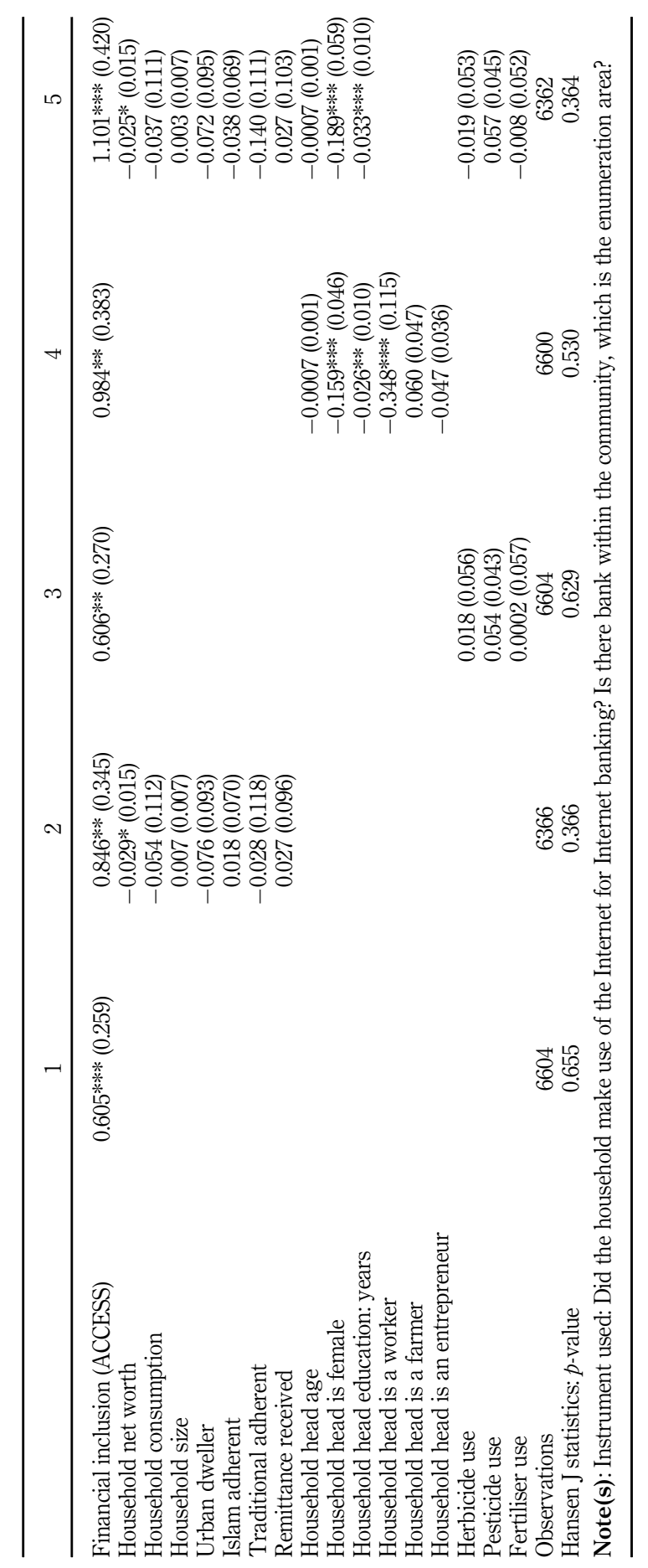

Table 2.

Effects of financial inclusion (ACCESS) on agricultural productivityinstrumental variable estimation 


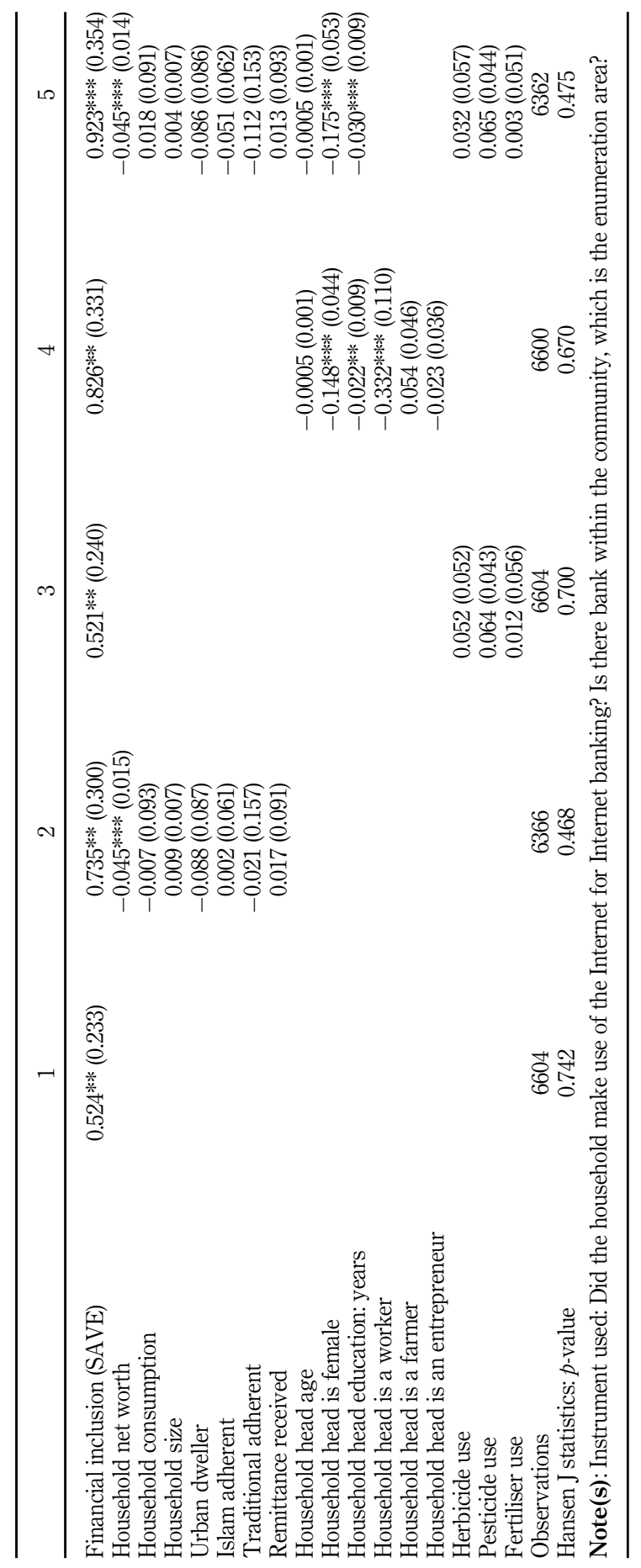

Agricultural
roductivity in
Nigeria

71

Table 3.

Effects of financial inclusion (SAVE) on agricultural productivity instrumental variable estimation 
JED

72

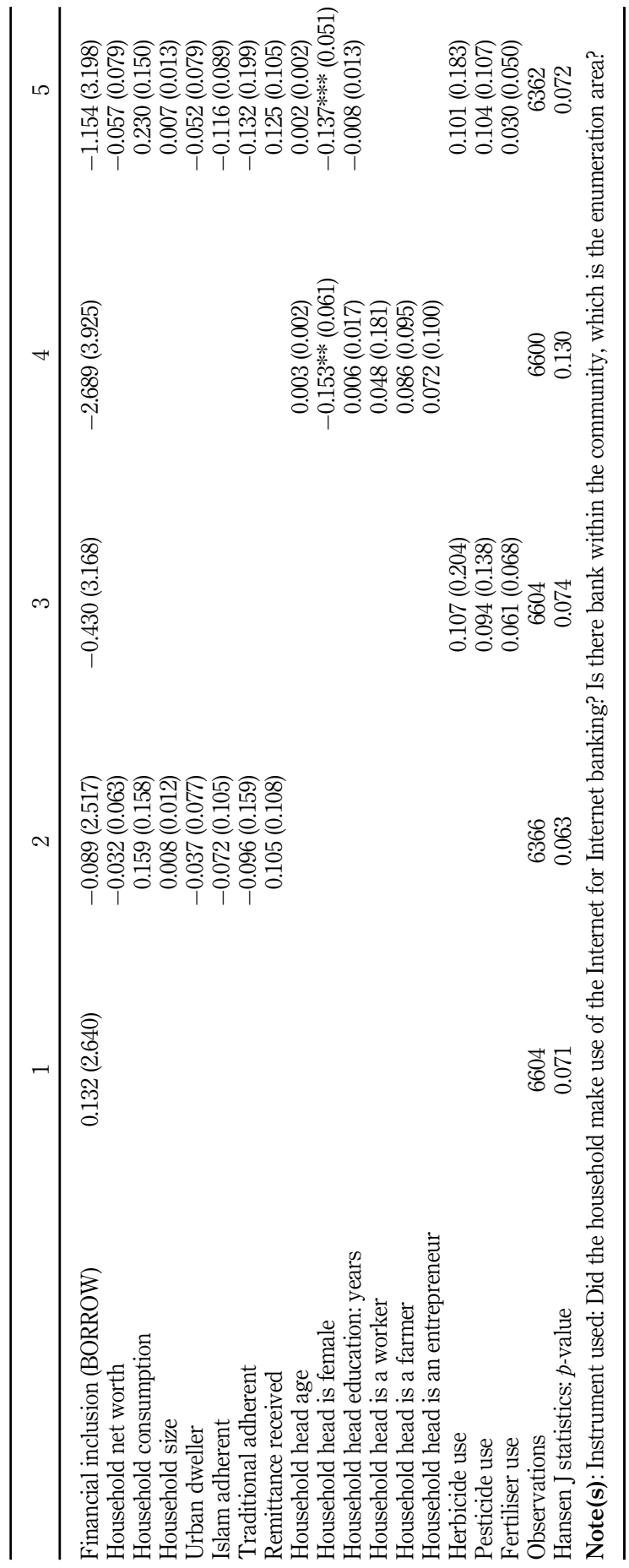

Table 4.

Effects of financial inclusion (BORROW) on agricultural productivity Instrumental variable estimation 
community, while the second instrumental variable is the use of the Internet for Internet banking.

Table 2 presents the results of instrumental variable estimation using access as the measure of financial inclusion. Different specifications are estimated. The coefficient of financial inclusion, represented by having access to an account in a financial institution, is positive and statistically significant in all specifications. Financial inclusion is significantly positive in column 1 , where it is the only explanatory variable, and also significant in column 5 , where all the household variables and agricultural input variables have been included. Thus, financial inclusion has stimulated increases in agricultural productivity of these households in Nigeria. These results highlight the importance of the financial sector in boosting agricultural productivity.

For the household variables, only the variable capturing household net worth is marginally significant at the $10 \%$ level. This variable is negative, implying that high net worth households have lower agricultural productivity. For the household head variables, the variables capturing gender, education and worker status are all statistically significant. The household head female dummy variable is negative, implying that female-headed households are associated with lower agricultural productivity. This might be due to the dominant role that large families (comprising many wives and children) play in providing farm labour. With female-headed households, it would not be possible to have such abundant supply of labour, and this could be negatively affecting productivity. The variable representing education of household heads is also significant negative. Thus, higher levels of education of household heads limit agricultural productivity. This might be reflective of the fact that time spent in education might have been used to gain experience on the fields. The dummy variable capturing if the household head works elsewhere is negative and statistically significant. This is indicative of the fact that working elsewhere draws the household head away from the agricultural activities, thereby resulting in low-quality time spent on the farm.

Table 3 presents the estimation results when the financial inclusion measure is savings in financial institutions. The results are consistent with the results from Table 2. Financial inclusion, measured by savings, is positive and statistically significant in all specifications. Thus, as concluded from Table 2, financial inclusion has led to increased agricultural productivity of the Nigerian farming households. The other variables can be interpreted similarly to Table 2. Household net worth, household head gender, household head education and household head being a worker are all negative and significant. Thus, as was concluded in Table 2, these variables contribute to declining agricultural productivity.

Table 4 presents the results when the financial inclusion measure is borrowing from a financial institution. Financial inclusion, and indeed all other variables, except the household head gender variable, are insignificant. The insignificance of the financial inclusion measure of borrowing could be connected with the fact that borrowing costs are so high in Nigeria. As indicated under the descriptive statistics, the high borrowing costs deter many people involved in agricultural activities from borrowing. Thus, borrowing does not exert any significant effect on agricultural productivity.

\subsection{Robustness tests}

We next test for the robustness of the estimated results presented in Tables 2-4. The robustness tests are presented in Tables 5 and 6 . In Table 5, the robustness tests are conducted by estimating fixed effects estimations using the dependent variable in Tables 2-4 - the crop income per hectare. For Table 6, we change the dependent variable and then estimate fixed effects estimations. For columns 1 to 3 in Table 6 , the dependent variable is the count of the number of crop groups harvested, while in columns 4 to 6 , the 
JED

74

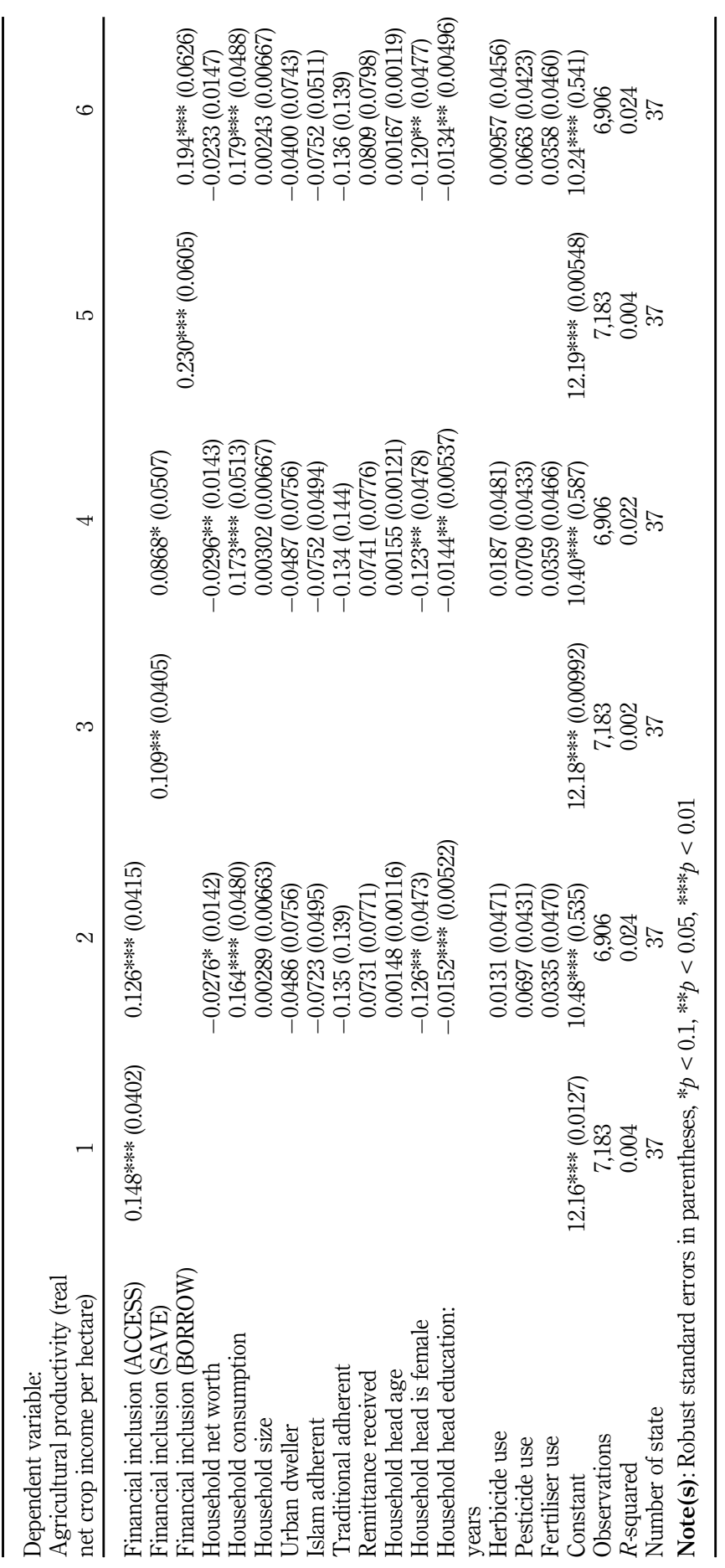

Table 5.

Effects of financial inclusion on agricultural productivity - fixed effects estimation 


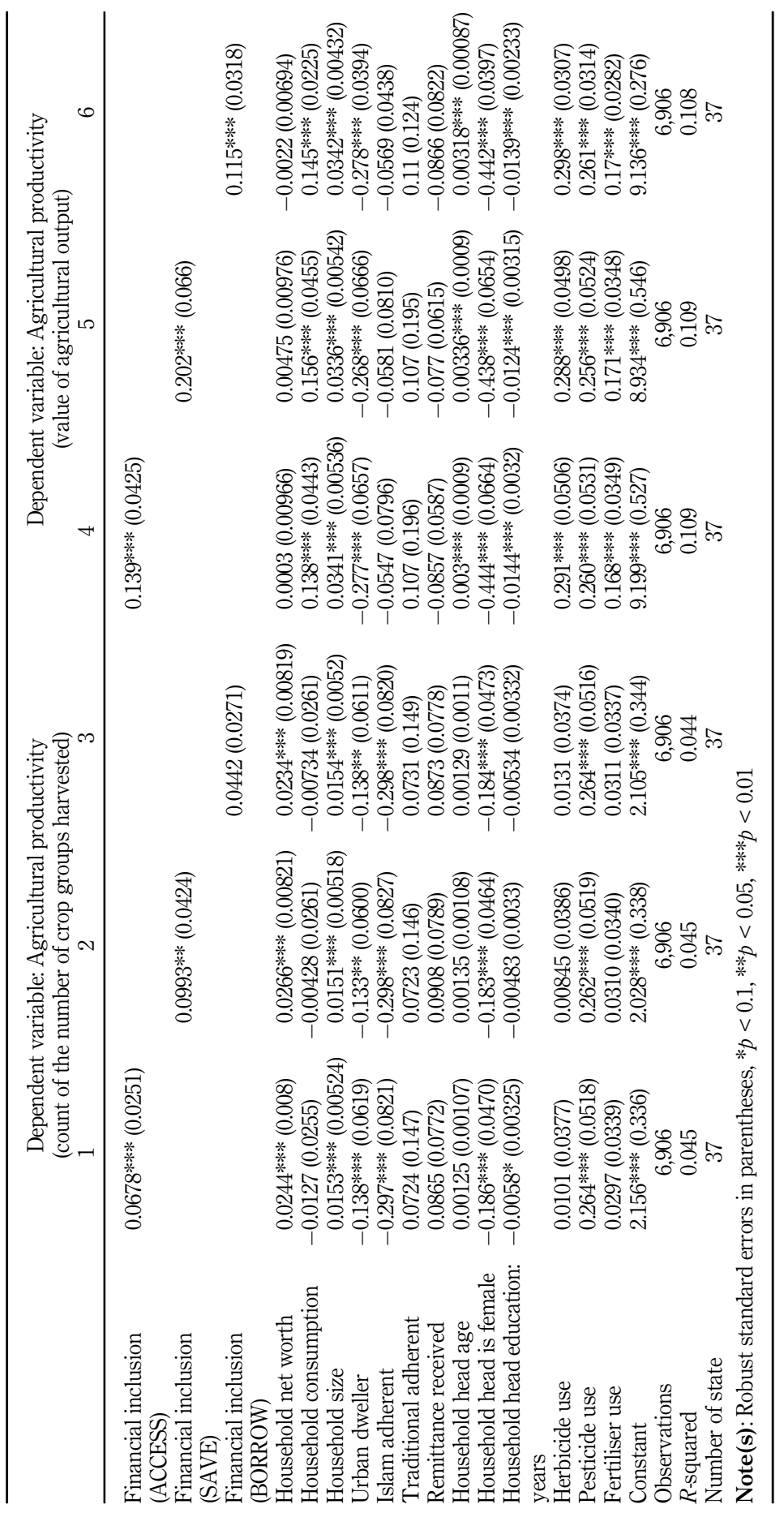

Agricultural productivity in Nigeria

Table 6. Effects of financial inclusion on agricultural productivity - fixed effects estimation 
JED

22,1

dependent variable is the value of agricultural output (agricultural revenue). These variables have been used by other studies (Dillon et al., 2015; Oseni et al., 2015) to measure agricultural productivity.

For the count of number of crop groups harvested, crops grown by households are classified into six groups: cereals/grains, legume, root and tuber, fruit and vegetables and non-food. Thus, the value of crop groups grown ranges from the lowest value of 1 to the highest value of 6 . A value of 1 implies that the household only cultivated and harvested one crop group, whereas a value of 6 implies that the household cultivated all the six crop groups and then harvested them during the last harvested period. A high value of crop groups grown by the household connotes high agricultural productivity because the household was able to cultivate variety of crops.

From Table 5, the fixed effects estimations corroborate the results from the instrumental variable estimations. All measures of financial inclusion (access, savings and borrowing) are positive and statistically significant. Thus, as concluded from the instrumental variables estimation, financial inclusion has been associated with increases in agricultural productivity for these Nigerian households. The results for household and household head characteristics are also similar to those obtained from the instrumental variable estimation. Household net worth, household head gender and household head education are significant negative, thus confirming results obtained earlier. Interestingly, the variable capturing household has positive and statistically significant coefficients.

When we use alternative definitions of agricultural productivity, Table 6 reveals that the results are consistent with what we obtained previously. Whether the dependent variable has changed to the count of the number of crop groups harvested, or whether it has changed to the value of agricultural output, financial inclusion still positively and significantly affects agricultural productivity. The results in Table 6 show that financial inclusion, irrespective of how it is measured, exerts positive and statistically significant effects on agricultural productivity. Thus, households that are financially included generate higher productivity from their agricultural activities than households that are financial excluded.

\section{Conclusion}

This study has conducted an empirical analysis of the effects of financial inclusion on agricultural productivity in Nigeria. We made use of a new panel data set from the LSMS-ISA to examine the behaviour of agricultural households. The empirical results showed that financial inclusion, irrespective of how it is measured, has exerted positive and statistically significant effects on agricultural productivity in Nigeria. Thus, it is important for financial inclusion efforts to be further intensified so that more agricultural households can be captured in the financial system. This will further enhance agricultural productivity.

These results have a number of implications. First, the results support the drive of the Central Bank of Nigeria to promote financial inclusion in the country. The central bank introduced the National Financial Inclusion Strategy in 2012, with the objective of increasing financial inclusion from $36 \%$ to $70 \%$ by 2020 . Drawing on lessons learnt, the central bank released a revised financial inclusion strategy in 2018. The primary goal of the revised financial inclusion strategy is to reduce financial exclusion to $20 \%$ by 2020 . Our empirical results show that improvements in financial inclusion will be beneficial to agricultural productivity.

Second, our results show that the variables measuring (1) account ownership and (2) savings are consistently associated with significant positive effects on agricultural productivity, unlike the variable measuring borrowing. This might be reflective of the high cost of borrowing predominant in Nigeria, which ultimately erodes any benefits of 
borrowing. Nigeria has numerous schemes established to make lending to agriculture readily available and cheap. These include Agricultural Credit Guarantee Scheme Fund, Agricultural Credit Support Scheme and Commercial Agriculture Credit Scheme. Unfortunately, it has been generally difficult for actual people engaged in agriculture to access these schemes. Based on our findings that access to finance positively affects agricultural productivity, policy-makers need to make these schemes available for farmers.

Also, our results show that female-headed households are associated with lower agricultural productivity. This result brings to light the patriarchal nature of agricultural production in Nigeria. However, an increasing number of research has shown that poverty falls faster for female-headed households in Africa (Beegle et al., 2016). Thus, it would be beneficial if policy-makers put in place policies favourable to women to participate in agriculture, so that their productivity can increase.

Finally, our results show that households with highly educated heads have lower agricultural productivity. This reflects the fact that agriculture in Nigeria is predominantly practised by small-holder farmers with little or no technological innovation, leading to low yields. If the country is going to increase production and yields, there is the need to embrace technology in agriculture. To achieve this, policy-makers need to encourage educated people to get involved in agriculture.

\section{References}

Ali, D., Bowen, D., Deininger, K. and Duponchel, M. (2016), "Investigating the gender gap in agricultural productivity: evidence from Uganda”, World Development, Vol. 87, pp. 152-170.

Amare, M., Jensen, N.D., Shiferaw, B. and Cisse, J.D. (2018), "Rainfall shocks and agricultural productivity: implication for rural household consumption”, Agricultural Systems, Vol. 166, pp. 79-89.

Anzoategui, D., Demirguc-Kunt, A. and Peria, M.S.M. (2014), "Remittances and financial inclusion: evidence from El Salvador", World Development, Vol. 54, pp. 338-349.

Aregheore, E.M. (2009), Nigeria: Country Pasture/Forage Resource Profiles, Food and Agriculture Organization of the United Nations, Rome.

Beck, T., Demirguc-Kunt, A. and Levine, R. (2007), "Finance, inequality and poverty: cross-country evidence", Journal of Economic Growth, Vol. 12, pp. 27-49.

Beegle, K., Christiaensen, L., Dabalen, A. and Gaddis, I. (2016), Poverty in a Rising Africa, Washington D.C., World Bank.

Central Bank of Nigeria (2019), Statistical Bulletin, Central Bank of Nigeria, Abuja.

Central Bank of Nigeria (2018), National Financial Inclusion Strategy (Revised), Central Bank of Nigeria, Abuja.

CGAP (2012), Financial Inclusion and Stability: What Does Research Show?, CGAP Brief, Consultative Group to Assist the Poor, Washington D.C.

Chigumira, G. and Masiyandima, N. (2003), "Did financial sector reform result in increased savings and lending for the SMEs and the poor?", IFLIP Research Paper 03-7, Geneva, International Labor Organization.

Clarke, G.R.G., Xu, L.C. and Zou, H.F. (2006), "Finance and income inequality: what do the data tell us?", Southern Economic Journal, Vol. 72, pp. 578-596.

Darko, F.A., Palacios-Lopez, A., Kilic, T. and Ricker-Gilbert, J. (2018), "Micro-level welfare impacts of agricultural productivity: evidence from rural Malawi", Journal of Development Studies, Vol. 54, pp. 915-932.

Demirguc-Kunt, A. and Klapper, L. (2012), "Measuring financial inclusion: the global Findex", Policy Research Working Paper WPS6025, World Bank, Washington, D.C. 
JED

22,1

Demirguc-Kunt, A. and Klapper, L. (2013), Measuring Financial Inclusion: Explaining Variation in Use of Financial Services across and within Countries, Brookings Papers on Economic Activity, Spring, pp. 279-321.

Dewett, K.K. and Singh, G. (1966), Indian Economics, Premier Publication Co., Delhi.

Dillon, A., McGee, K. and Oseni, G. (2015), "Agricultural production, dietary diversity, and climate variability”, Journal of Development Studies, Vol. 51, pp. 976-995.

EFINA (2017), "Key findings: access to financial services survey in Nigeria 2016 survey”, Lagos, Enhancing Financial Innovation and Access.

Fowowe, B. and Folarin, E.O. (2019), "The effects of fragility and financial inequalities on inclusive growth in african countries", Review of Development Economics, Vol. 23, pp. 1141-1176.

Global Financial Development Report (2014), Financial Inclusion, World Bank, Washington D.C.

International Finance Corporation (2011), Toward Universal Access: Addressing the Global Challenge of Financial Inclusion, International Finance Corporation, Washington D.C.

King, R. and Levine, R. (1993), "Finance and growth: schumpeter might be right", Quarterly Journal of Economics, Vol. 108, pp. 717-737.

Levine, R. (2005), "Finance and growth: theory and evidence", in Aghion, P. and Durlauf, S. (Eds.), Handbook of Economic Growth, Vol. 1, North-Holland Elsevier, Amsterdam, pp. 865-934.

Manyong, V.M., Ikpi, A., Olayemi, J.K., Yusuf, S.A., Omonona, B.T., Okoruwa, V. and Idachaba, F.S. (2005), Agriculture in Nigeria: Identifying Opportunities for Increased Commercialization and Investment, Ibadan, IITA.

McKinsey Global Institute (2010), Lions on the Move: The Progress and Potential of African Economies, McKinsey \& Company, London.

McKinsey Global Institute (2014), Nigeria's Renewal: Delivering Inclusive Growth in Africa's Largest Economy, McKinsey \& Company, London.

Nathan Associates (2015), "The intersection of agricultural and financial markets”, Final Report.

National Bureau of Statistics (2010), National Manpower Stock and Employment Generation Survey, National Bureau of Statistics, Abuja.

National Bureau of Statistics (2013), National Baseline Youth Survey, National Bureau of Statistics, Abuja.

National Bureau of Statistics (2015a), Basic Information Document: Nigeria General Household Survey Panel, 2010-2011, National Bureau of Statistics, Abuja.

National Bureau of Statistics (2015b), Basic Information Document: Nigeria General Household SurveyPanel, 2012/13, National Bureau of Statistics, Abuja.

National Bureau of Statistics (2016), LSMS-integrated Surveys on Agriculture: General Household Survey Panel 2015/2016, National Bureau of Statistics, Abuja.

National Bureau of Statistics (2019), Selected Banking Sector Data Q3 2019, National Bureau of Statistics, Abuja.

Oseni, G., McGee, K. and Dabalen, A. (2014), "Can agricultural households farm their way out of poverty?", Policy Research Working Paper WPS7093, World Bank, Washington D.C.

Oseni, G., Corral, P., Goldstein, M. and Winters, P. (2015), "Explaining gender differentials in agricultural production in Nigeria", Agricultural Economics, Vol. 46, pp. 285-310.

Pasali, S.S. (2013), "Where is the cheese? Synthesizing a giant literature on causes and consequences of financial sector development”, Policy Research Working Paper WPS6655, World Bank, Washington D.C.

Rajan, R.G. and Zingales, L. (2001), "The great reversals: the politics of financial development in the 20th century", NBER Working Paper 8178, National Bureau of Economic Research, Cambridge. 
Soumare, I., Tchana, F.T. and Kengne, T.M. (2016), "Analysis of the determinants of financial inclusion in west and central Africa", Transnational Corporations Review, Vol. 8, pp. 231-249.

Agricultural productivity in Nigeria

Corresponding author

Babajide Fowowe can be contacted at: babafowowe@hotmail.com

For instructions on how to order reprints of this article, please visit our website: www.emeraldgrouppublishing.com/licensing/reprints.htm Or contact us for further details: permissions@emeraldinsight.com 